\title{
Mamuju City Development and Its Hinterland
}

\author{
Muhammad Agung Ady Mangilep ${ }^{1}$, Hamrullah $^{2}$, Sanusi Fattah $^{3}$ \\ \{agungam@fe.unhas.ac.id ${ }^{1}$, hamrullah@fe.unhas.ac.id ${ }^{2}$, sanusi_fattah@fe.unhas.ac.id ${ }^{3}$ \} \\ Faculty of Economics and Business, Hasanuddin University, Makassar, Indonesia. ${ }^{1-3}$
}

\begin{abstract}
This study is aimedto explore the potential relation between Mamuju City and its hinterlands to improve their economies. Quantitative data is obtained from some publications from Indonesian government. This research uses LQ method to analyze economic basic sectors. Analysis of economic relation between hinterlands and the city is explained by a descriptive statistic. This research finds that several sectors can be expanded to improve Mamuju City's regional economy.
\end{abstract}

Keywords:

basic sector, hinterland, regional development

Article Received: 18 October 2020, Revised: 3 November 2020, Accepted: 24 December 2020

\section{Introduction}

Mamuju Regency is the capital of West Sulawesi Province which located at the eastern region of Indonesia. West Sulawesi is one of the newest provinces in Indonesia which was emerged in the period of Indonesian regional autonomy system after a reform on Indonesian bureaucratic system in the middle of 1998. The emerging of West Sulawesi Province would be a solution to reduce development gap in the northwest area of South Sulawesi Province, the parent region. West Sulawesi Province has supported various economic growth programs, but its per capita income is still below the average of Indonesian per capita income. A strategic role of Mamuju Regency, to promote a faster growth of its hinterland regencies, can be a relevant solution to increase the provincial income.

This study is aimed to examinea role ofMamuju Regencyto promote growths of its hinterlands. That role can be shown by identifying several sectors in hinterlands of Mamuju Regency which contributions are lower than those at the provincial level. Increasing contributionsmay increase growths of Mamuju Regency's hinterlands.

The most important perspective for the growth of an area in a trade system is a regional perspective of an area development. By improving an intersector relation, an area can promote its role as a center of trading activities where others surrounded relate their economic activities. Berliant (2005) defines a central place is the top of hierarchical coordination of a marketplace interm of spatial analysis. Currently, a development of hinterland regions hasbecome an important perspective in a development of a central area. Welman, et al (2016) points out that poverty reduction and employment creation programs in hinterlands can be promoted by a port development in a central area. OECD (2008) states that ports have a role as supply chains to hinterlands. Visser, et al (2007) points out a developmentof hinterlands surrounded a port city.

\section{Research Methodology}

Location Quotient or LQ is a method to measure a contribution of aSector 13 in a local area to a whole region. Hanif, et al (2015) states that LQ can be used to expose disparities in a region. Ascani, et al (2012) states that LQ can be used to expose spatial inequalities. Srotebeck (2010) points out that LQ can be used toidentify area clusters.

LQ is used in my research to measure a value which shows a contribution of a local Gross 
Domestic Regional Product (or GDRP) to its region.

$$
\mathrm{LQ}=\left(\mathrm{x}_{-\mathrm{i}} / \mathrm{x}_{-\mathrm{j}}\right)\left(\mathrm{X}_{-} \mathrm{i} / \mathrm{X}_{-\mathrm{j}}\right)
$$

where, $x_{-} i=\mathrm{a}$ GDRP of a sector in a local area

$\mathrm{x}_{-\mathrm{j}}=\mathrm{a}$ total GDRP of a sector in a local area

$X_{-j}=a$ GDRP of a sector in a regional area

$X_{-j}=a$ total GDRP of a sector in a regional area

A basic sectoris defined as anLQ's value which equal or higher than 1, otherwise is defined as a non-basic sector. The basic sector can be defined as a more rapid growth sector than the non-basic one.

Based on economic sectors categorized by Indonesian Bureau of Statistics, we define sectors as follows.

- Sector 1 is the agriculture,

- Sector 2 is the mining,

- Sector 3 is manufactured industry,

- Sector 4 is power and electricity,

- Sector 5 is water and sewages,

- Sector 6 is constructions,

- Sector 7 istrade and retails,

- Sector 8 is transportation and warehousing,

- Sector 9 is hotel and restaurants,

- Sector 10 is information and communication,

- Sector 11 is finance and insurance,

- Sector 12 is real estates,

- Sector 13 is business services,

- Sector 14 is government, defense and social security,

- Sector 15 is the education,

- Sector 16 is health and social activities,

- Sector 17 is ungrouped services.

\section{Result and Discussion}

The total GDRP of Mamuju Regency has reached $\mathrm{Rp} 10,051.75$ billion along with a fluctuated trend of growthsduring 2010 to 2017 (BPS Mamuju 2019). In that period, Mamuju Regency's economy grew 13.45on average. Mamuju Regency's sectoral GDRP on 2017 is shown at Table 1.

Table 1. Sectoral GDRP distribution of Mamuju Regency at current prices on 2017 (BPS Mamuju 2019)

\begin{tabular}{|c|r|}
\hline Sectors & \multicolumn{1}{|c|}{$\begin{array}{c}\text { GDRP } \\
\text { (in billion } \\
\text { Rupiah) }\end{array}$} \\
\hline 1 & 3692.07 \\
2 & 338.74 \\
3 & 333.44 \\
4 & 5.01 \\
5 & 33.65 \\
6 & 1024.43 \\
7 & 1028.59 \\
8 & 191.46 \\
9 & 24.87 \\
10 & 674.75 \\
11 & 279.22 \\
12 & 213.94 \\
13 & 8.28 \\
14 & 1202.57 \\
15 & 511.59 \\
16 & 211.03 \\
17 & 278.08 \\
\hline Total & 10051.75 \\
\hline
\end{tabular}

A GDRP distribution can be also presented by main groups of economic sectors. The primary sector has contributed 39.57percent on average, from the total GDRP. The secondary sector has contributed 16.38 per cent. Tertiary sector has contributed 44.05 per cent. The most important sector in Mamuju is the tertiary one. GDRP distributions by main groups of economic sectorsduring 2010 to 2017are presented in Table 2.

Table 2. GDRP allocations of Mamuju Regency at current prices (processed data from Table 1)

\begin{tabular}{|c|l|l|l|l|l|l|l|l|}
\hline $\begin{array}{c}\text { Main } \\
\text { Sectors }\end{array}$ & 2010 & 2011 & 2012 & 2013 & 2014 & 2015 & 2016 & 2017 \\
\hline
\end{tabular}




\begin{tabular}{|l|r|r|r|r|r|r|r|r|}
\hline Primary & 39.95 & 40.03 & 39.04 & 39.08 & 39.07 & 39.78 & 39.52 & 40.10 \\
Secondary & 18.20 & 16.90 & 16.18 & 15.73 & 16.04 & 15.99 & 15.99 & 16.02 \\
Tertiary & 41.85 & 43.06 & 44.78 & 45.19 & 44.89 & 44.23 & 44.49 & 43.88 \\
\hline Total & 100.00 & 100.00 & 100.00 & 100.00 & 100.00 & 100.00 & 100.00 & 100.00 \\
\hline
\end{tabular}

Table 3 shows the results of LQ calculations on GDRP of Mamuju Regency in the period 20102017. From the table, we can calculate averageLQ values for each economic sector described as follows. The LQ value of Sector 1 is 0.87 and it is defined as a non-basic sector.The LQ value of Sector 2 is 1.50 and it is defined as a basic sector. The LQ value of Sector 3is 0.35 and it is defined as a non-basic sector.The LQ value of Sector 4 is 1.27and it is defined as a basic sector.The LQ value of Sector 5 is 2.25 and it is defined as a basic sector. The LQ value of construction sector 6 is 1.26and it is defined as a basic sector. The LQ value of Sector 7 is 1.01 and it is defined as a basic
sector.The LQ value of Sector 8 is 1.32and it is defined as a basic sector.The LQ value of Sector 9 is 1.12 and it is defined as a basic sector. The LQ value of Sector 10 is 1.69 and it is defined as a basic sector. The LQ value of Sector 11 is 1.31 and it is defined as a basic sector.The LQ value of Sector 12 is 0.80 and it is defined as a non-basic sector.The LQ value of Sector 13 is 1.21 and it is defined as a basic sector.The LQ value of Sector 14 is 1.47 and it is defined as a basic sector.The LQ value of Sector 15 is 1.03 and it is defined as a basic sector. The LQ value of Sector 16 is 1.06 it is defined as a basic sector. The LQ value of Sector 17 is 1.53 it is defined as a basic sector.

Table 3. Sectoral LQs of Mamuju Regency (processed data from Table 1)

\begin{tabular}{|c|r|r|r|r|r|r|r|r|}
\hline Sectors & 2010 & 2011 & 2012 & 2013 & 2014 & 2015 & 2016 & 2017 \\
\hline 1 & 0.84 & 0.86 & 0.86 & 0.85 & 0.86 & 0.87 & 0.87 & 0.88 \\
2 & 1.64 & 1.58 & 1.54 & 1.50 & 1.52 & 1.51 & 1.47 & 1.49 \\
3 & 0.43 & 0.42 & 0.42 & 0.41 & 0.34 & 0.32 & 0.33 & 0.33 \\
4 & 1.27 & 1.30 & 1.26 & 1.25 & 1.28 & 1.26 & 1.29 & 1.28 \\
5 & 2.04 & 2.06 & 2.13 & 2.21 & 2.25 & 2.22 & 2.31 & 2.27 \\
6 & 1.48 & 1.34 & 1.28 & 1.22 & 1.28 & 1.28 & 1.25 & 1.25 \\
7 & 0.98 & 1.00 & 1.01 & 1.02 & 1.03 & 1.02 & 0.99 & 0.99 \\
8 & 1.35 & 1.34 & 1.33 & 1.29 & 1.31 & 1.29 & 1.34 & 1.36 \\
9 & 1.07 & 1.12 & 1.12 & 1.14 & 1.14 & 1.13 & 1.10 & 1.08 \\
10 & 1.63 & 1.64 & 1.65 & 1.65 & 1.72 & 1.71 & 1.70 & 1.69 \\
11 & 1.37 & 1.37 & 1.36 & 1.36 & 1.37 & 1.35 & 1.23 & 1.25 \\
12 & 0.82 & 0.80 & 0.79 & 0.78 & 0.81 & 0.82 & 0.80 & 0.80 \\
13 & 1.32 & 1.26 & 1.26 & 1.22 & 1.24 & 1.23 & 1.19 & 1.19 \\
14 & 1.32 & 1.37 & 1.37 & 1.42 & 1.49 & 1.49 & 1.48 & 1.49 \\
15 & 1.10 & 1.07 & 1.01 & 1.03 & 1.06 & 1.05 & 1.02 & 1.01 \\
16 & 1.12 & 1.08 & 1.00 & 1.04 & 1.06 & 1.06 & 1.07 & 1.07 \\
17 & 1.28 & 1.30 & 1.47 & 1.49 & 1.56 & 1.56 & 1.52 & 1.53 \\
\hline
\end{tabular}

Table 4 shows the results of LQ calculations on GDRP of Majene Regency in the period 20102017. From the table, we can calculate average LQ values for each economic sector described as follows. The LQ value of Sector 1 is 0.84 and it is defined as a non-basic sector. The LQ value of
Sector 2 is 1.23 and it is defined as a basic sector. The LQ value of Sector 3 is 0.53 and it is defined as a non-basic sector. The LQ value of Sector 4 is 1.79 and it is defined as a basic sector. The LQ value of Sector 5 is 0.78 and it is defined as a nonbasic sector. The LQ value of construction sector 
is 0.88 and it is defined as a non-basic sector. The LQ value of Sector 7 is 1.06 and it is defined as a basic sector. The LQ value of Sector 8 is 1.20 and it is defined as a basic sector. The LQ value of Sector 9 is 1.21 and it is defined as a basic sector. The LQ value of Sector 10 is 1.24 and it is defined as a basic sector. The LQ value of Sector 11 is 1.64 and it is defined as a basic sector. The LQ value of Sector 12 is 1.27 and it is defined as a basic sector. The LQ value of Sector 13 is 0.67 and it is defined as a non-basic sector. The LQ value of Sector 14 is 1.37 and it is defined as a basic sector. The LQ value of Sector 15 is 1.75 it is defined as a basic sector. The LQ value of Sector 16 is 0.71 it is defined as a non-basic sector. The LQ value of Sector 17 is 1.75 it is defined as a basic sector.

Table 4. Sectoral LQs of Majene Regency (processed data from BPS Majene 2019)

\begin{tabular}{|c|c|c|c|c|c|c|c|c|}
\hline Sectors & 2010 & 2011 & 2012 & 2013 & 2014 & 2015 & 2016 & 2017 \\
\hline 1 & 0.86 & 0.86 & 0.85 & 0.84 & 0.85 & 0.84 & 0.84 & 0.85 \\
2 & 1.10 & 1.10 & 1.13 & 1.21 & 1.27 & 1.28 & 1.19 & 1.20 \\
3 & 0.67 & 0.65 & 0.64 & 0.62 & 0.48 & 0.49 & 0.53 & 0.51 \\
4 & 1.63 & 1.58 & 1.77 & 1.73 & 1.76 & 1.83 & 1.86 & 1.79 \\
5 & 0.91 & 0.79 & 0.74 & 0.77 & 0.81 & 0.78 & 0.80 & 0.76 \\
6 & 0.95 & 0.94 & 0.93 & 0.90 & 0.90 & 0.89 & 0.85 & 0.87 \\
7 & 0.94 & 1.02 & 1.01 & 1.02 & 1.06 & 1.07 & 1.07 & 1.09 \\
8 & 1.13 & 1.16 & 1.14 & 1.13 & 1.21 & 1.25 & 1.22 & 1.21 \\
9 & 1.11 & 1.10 & 1.10 & 1.14 & 1.21 & 1.23 & 1.24 & 1.24 \\
10 & 1.02 & 1.04 & 1.19 & 1.20 & 1.23 & 1.24 & 1.25 & 1.26 \\
11 & 1.66 & 1.59 & 1.58 & 1.58 & 1.63 & 1.66 & 1.72 & 1.62 \\
12 & 1.09 & 1.13 & 1.17 & 1.23 & 1.26 & 1.29 & 1.28 & 1.29 \\
13 & 0.59 & 0.63 & 0.63 & 0.62 & 0.66 & 0.68 & 0.68 & 0.68 \\
14 & 1.52 & 1.40 & 1.31 & 1.34 & 1.42 & 1.43 & 1.34 & 1.34 \\
15 & 1.59 & 1.60 & 1.61 & 1.63 & 1.76 & 1.82 & 1.77 & 1.79 \\
16 & 0.69 & 0.67 & 0.65 & 0.69 & 0.72 & 0.73 & 0.70 & 0.71 \\
17 & 1.96 & 1.96 & 1.86 & 1.81 & 1.77 & 1.77 & 1.72 & 1.68 \\
\hline
\end{tabular}

Table 5 shows the results of LQ calculations on GDRP of Polewali Mandar Regency in the period 2010-2017. From the table, we can calculate average LQ values for each economic sector described as follows. The LQ value of Sector 1 is 0.97 and it is defined as a non-basic sector. The LQ value of Sector 2 is 1.02 and it is defined as a basic sector. The LQ value of Sector 3 is 0.52 and it is defined as a non-basic sector. The LQ value of Sector 4 is 1.10 and it is defined as a basic sector. The LQ value of Sector 5 is 1.02 and it is defined as a basic sector. The LQ value of construction sector is 0.99 and it is defined as a non-basic sector. The LQ value of Sector 7 is 1.50 and it is defined as a basic sector. The LQ value of
Sector 8 is 0.89 and it is defined as a non-basic sector. The LQ value of Sector 9 is 1.14 and it is defined as a basic sector. The LQ value of Sector 10 is 1.13 and it is defined as a basic sector. The LQ value of Sector 11 is 1.18 and it is defined as a basic sector. The LQ value of Sector 12 is 1.30 and it is defined as a basic sector. The LQ value of Sector 13 is 1.28 and it is defined as a basic sector. The LQ value of Sector 14 is 0.85 and it is defined as a non-basic sector. The LQ value of Sector 15 is 0.95 it is defined as a non-basic sector. The LQ value of Sector 16 is 1.22 it is defined as a basic sector. The LQ value of Sector 17 is 1.17 it is defined as a basic sector. 
Table 5. Sectoral LQ of Polewali Mandar Regency (processed data from BPS Polewali Mandar 2019)

\begin{tabular}{|c|c|c|c|c|c|c|c|c|}
\hline Sectors & 2010 & 2011 & 2012 & 2013 & 2014 & 2015 & 2016 & 2017 \\
\hline 1 & 0.94 & 0.94 & 0.93 & 0.93 & 0.95 & 0.96 & 0.97 & 1.04 \\
2 & 0.97 & 1.01 & 1.02 & 1.01 & 1.03 & 1.00 & 0.99 & 1.07 \\
3 & 0.74 & 0.69 & 0.70 & 0.74 & 0.61 & 0.61 & 0.63 & 0.00 \\
4 & 1.35 & 1.29 & 1.14 & 1.11 & 1.13 & 1.13 & 1.04 & 1.09 \\
5 & 1.08 & 1.07 & 1.07 & 1.03 & 1.02 & 1.00 & 0.97 & 1.05 \\
6 & 0.90 & 0.98 & 0.98 & 0.97 & 0.99 & 0.99 & 0.96 & 1.03 \\
7 & 1.50 & 1.48 & 1.46 & 1.45 & 1.50 & 1.48 & 1.47 & 1.59 \\
8 & 0.87 & 0.89 & 0.88 & 0.87 & 0.89 & 0.89 & 0.86 & 0.93 \\
9 & 1.13 & 1.13 & 1.09 & 1.11 & 1.14 & 1.12 & 1.12 & 1.20 \\
10 & 1.20 & 1.14 & 1.12 & 1.10 & 1.15 & 1.12 & 1.12 & 1.17 \\
11 & 1.07 & 1.11 & 1.11 & 1.11 & 1.14 & 1.14 & 1.20 & 1.30 \\
12 & 1.19 & 1.21 & 1.25 & 1.28 & 1.32 & 1.29 & 1.28 & 1.35 \\
13 & 1.14 & 1.21 & 1.20 & 1.25 & 1.29 & 1.27 & 1.26 & 1.34 \\
14 & 0.86 & 0.83 & 0.84 & 0.84 & 0.84 & 0.88 & 0.84 & 0.87 \\
15 & 0.86 & 0.91 & 0.95 & 0.95 & 0.95 & 0.95 & 0.93 & 0.98 \\
16 & 1.23 & 1.24 & 1.21 & 1.21 & 1.23 & 1.22 & 1.18 & 1.28 \\
17 & 1.21 & 1.24 & 1.21 & 1.19 & 1.20 & 1.14 & 1.14 & 1.21 \\
\hline
\end{tabular}

Table 6 shows the results of LQ calculations on GDRP of Pasangkayu Regency in the period 2010-2017. From the table, we can calculate average LQ values for each economic sector described as follows. The LQ value of Sector 1 is 1.11 and it is defined as a basic sector. The LQ value of Sector 2 is 0.47 and it is defined as a nonbasic sector. The LQ value of Sector 3 is 2.58 and it is defined as a non-basic sector. The LQ value of Sector 4 is 0.56 and it is defined as a non-basic sector. The LQ value of Sector 5 is 0.05 and it is defined as a non-basic sector. The LQ value of construction sector is 1.04 and it is defined as a basic sector. The LQ value of Sector 7 is 0.47 and it is defined as a non-basic sector. The LQ value of Sector 8 is 0.98 and it is defined as a non-basic sector. The LQ value of Sector 9 is 0.55 and it is defined as a non-basic sector. The LQ value of Sector 10 is 0.29 and it is defined as a non-basic sector. The LQ value of Sector 11 is 0.29 and it is defined as a non-basic sector. The LQ value of Sector 12 is 0.48 and it is defined as a non-basic sector. The LQ value of Sector 13 is 0.83 and it is defined as a non-basic sector. The LQ value of Sector 14 is 0.52 and it is defined as a non-basic sector. The LQ value of Sector 15 is 0.56 it is defined as a non-basic sector. The LQ value of Sector 16 is 1.00 it is defined as a basic sector. The LQ value of Sector 17 is 0.26 it is defined as a non-basic sector.

Table 6. Sectoral LQ of Pasangkayu Regency (processed data from BPS Pasangkayu2019)

\begin{tabular}{|c|r|r|r|r|r|r|r|r|}
\hline Sectors & 2010 & 2011 & 2012 & 2013 & 2014 & 2015 & 2016 & 2017 \\
\hline 1 & 1.18 & 1.18 & 1.19 & 1.17 & 1.10 & 1.09 & 1.10 & 1.07 \\
2 & 0.49 & 0.46 & 0.46 & 0.50 & 0.47 & 0.46 & 0.47 & 0.47 \\
3 & 2.36 & 2.32 & 2.38 & 2.38 & 2.55 & 2.64 & 2.67 & 2.64 \\
4 & 0.24 & 0.35 & 0.48 & 0.56 & 0.52 & 0.52 & 0.57 & 0.65 \\
5 & 0.04 & 0.04 & 0.04 & 0.04 & 0.05 & 0.05 & 0.06 & 0.06 \\
6 & 0.95 & 0.97 & 1.01 & 1.10 & 1.02 & 0.98 & 1.06 & 1.06 \\
7 & 0.50 & 0.50 & 0.50 & 0.49 & 0.46 & 0.47 & 0.48 & 0.47 \\
8 & 1.01 & 1.01 & 1.01 & 1.05 & 0.97 & 0.96 & 0.95 & 0.96 \\
\hline
\end{tabular}




\begin{tabular}{|c|c|c|c|c|c|c|c|c|}
\hline 9 & 0.58 & 0.58 & 0.58 & 0.58 & 0.54 & 0.54 & 0.54 & 0.54 \\
10 & 0.29 & 0.28 & 0.28 & 0.30 & 0.28 & 0.27 & 0.29 & 0.28 \\
11 & 0.28 & 0.31 & 0.31 & 0.31 & 0.29 & 0.28 & 0.30 & 0.30 \\
12 & 0.58 & 0.56 & 0.53 & 0.52 & 0.48 & 0.47 & 0.47 & 0.47 \\
13 & 0.96 & 0.95 & 0.92 & 0.89 & 0.82 & 0.79 & 0.81 & 0.82 \\
14 & 0.57 & 0.61 & 0.60 & 0.59 & 0.50 & 0.48 & 0.52 & 0.52 \\
15 & 0.51 & 0.55 & 0.55 & 0.57 & 0.54 & 0.54 & 0.57 & 0.57 \\
16 & 0.93 & 1.00 & 1.05 & 1.05 & 0.97 & 0.94 & 1.01 & 1.02 \\
17 & 0.25 & 0.27 & 0.27 & 0.27 & 0.25 & 0.25 & 0.26 & 0.25 \\
\hline
\end{tabular}

Table 7 shows the results of LQ calculations on GDRP of Central Mamuju Regency in the period 2010-2017. From the table, we can calculate average LQ values for each economic sector described as follows. The LQ value of Sector 1 is 1.70 and it is defined as a basic sector. The LQ value of Sector 2 is 0.55 and it is defined as a non-basic sector. The LQ value of Sector 3 is 0.91 and it is defined as a non-basic sector. The LQ value of Sector 4 is 0.35 and it is defined as a non-basic sector. The LQ value of Sector 5 is 0.38 and it is defined as a non-basic sector. The LQ value of construction sector is 0.17 and it is defined as a non-basic sector. The LQ value of Sector 7 is 0.45 and it is defined as a non-basic sector. The LQ value of Sector 8 is 0.43 and it is defined as a non-basic sector. The LQ value of Sector 9 is 0.83 and it is defined as a non-basic sector. The LQ value of Sector 10 is 0.26 and it is defined as a non-basic sector. The LQ value of Sector 11 is 0.40 and it is defined as a non-basic sector. The LQ value of Sector 12 is 1.26 and it is defined as a basic sector. The LQ value of Sector 13 is 0.19 and it is defined as a non-basic sector. The LQ value of Sector 14 is 0.32 and it is defined as a non-basic sector. The LQ value of Sector 15 is 0.71 it is defined as a non-basic sector. The LQ value of Sector 16 is 0.15 it is defined as a nonbasic sector. The LQ value of Sector 17 is 0.11 it is defined as a non-basic sector.

Table 7. Sectoral LQ of Central Mamuju Regency (processed data from BPS Mamuju Tengah 2019)

\begin{tabular}{|c|c|c|c|c|c|c|c|c|}
\hline Sectors & 2010 & 2011 & 2012 & 2013 & 2014 & 2015 & 2016 & 2017 \\
\hline 1 & N/A & N/A & N/A & 1.70 & 1.70 & 1.70 & 1.69 & 1.70 \\
2 & N/A & N/A & N/A & 0.55 & 0.59 & 0.55 & 0.55 & 0.54 \\
3 & N/A & N/A & N/A & 1.15 & 0.93 & 0.88 & 0.82 & 0.80 \\
4 & N/A & N/A & N/A & 0.34 & 0.35 & 0.35 & 0.35 & 0.34 \\
5 & N/A & N/A & N/A & 0.38 & 0.38 & 0.37 & 0.38 & 0.38 \\
6 & N/A & N/A & N/A & 0.14 & 0.17 & 0.17 & 0.18 & 0.18 \\
7 & N/A & N/A & N/A & 0.45 & 0.46 & 0.44 & 0.45 & 0.45 \\
8 & N/A & N/A & N/A & 0.43 & 0.44 & 0.43 & 0.43 & 0.43 \\
9 & N/A & N/A & N/A & 0.78 & 0.84 & 0.83 & 0.84 & 0.84 \\
10 & N/A & N/A & N/A & 0.25 & 0.26 & 0.26 & 0.26 & 0.26 \\
11 & N/A & N/A & N/A & 0.40 & 0.41 & 0.40 & 0.39 & 0.40 \\
12 & N/A & N/A & N/A & 1.18 & 1.27 & 1.28 & 1.28 & 1.30 \\
13 & N/A & N/A & N/A & 0.19 & 0.20 & 0.19 & 0.19 & 0.19 \\
14 & N/A & N/A & N/A & 0.13 & 0.19 & 0.28 & 0.50 & 0.49 \\
15 & N/A & N/A & N/A & 0.73 & 0.72 & 0.69 & 0.69 & 0.71 \\
16 & N/A & N/A & N/A & 0.15 & 0.15 & 0.15 & 0.15 & 0.15 \\
17 & N/A & N/A & N/A & 0.11 & 0.11 & 0.11 & 0.11 & 0.11 \\
\hline
\end{tabular}


Table 8 shows the results of LQ calculations on GDRP of Mamasa Regency in the period 20102017. From the table, we can calculate average LQ values for each economic sector described as follows. The LQ value of Sector 1 is 0.82 and it is defined as a non-basic sector. The LQ value of Sector 2 is 0.95 and it is defined as a non-basic sector. The LQ value of Sector 3 is 0.52 and it is defined as a non-basic sector. The LQ value of Sector 4 is 0.49 and it is defined as a non-basic sector. The LQ value of Sector 5 is 0.66 and it is defined as a non-basic sector. The LQ value of construction sector is 0.99 and it is defined as a non-basic sector. The LQ value of Sector 7 is 1.09 and it is defined as a basic sector. The LQ value of
Sector 8 is 0.73 and it is defined as a non-basic sector. The LQ value of Sector 9 is 1.47 and it is defined as a basic sector. The LQ value of Sector 10 is 0.82 and it is defined as a non-basic sector. The LQ value of Sector 11 is 1.07 and it is defined as a basic sector. The LQ value of Sector 12 is 1.66 and it is defined as a basic sector. The LQ value of Sector 13 is 1.10 and it is defined as a basic sector. The LQ value of Sector 14 is 1.72 and it is defined as a basic sector. The LQ value of Sector 15 is 1.93 it is defined as a basic sector. The LQ value of Sector 16 is 1.34 it is defined as a basic sector. The LQ value of Sector 17 is 0.59 it is defined as a non-basic sector.

Table 8. Sectoral LQ of Mamasa Regency (processed data from BPS Mamasa 2019)

\begin{tabular}{|c|r|r|r|r|r|r|r|r|}
\hline Sectors & 2010 & 2011 & 2012 & 2013 & 2014 & 2015 & 2016 & 2017 \\
\hline 1 & 0.90 & 0.86 & 0.85 & 0.84 & 0.83 & 0.82 & 0.80 & 0.80 \\
2 & 0.70 & 0.76 & 0.85 & 0.81 & 0.93 & 0.96 & 0.97 & 1.09 \\
3 & 0.59 & 0.61 & 0.62 & 0.65 & 0.49 & 0.47 & 0.49 & 0.50 \\
4 & 0.45 & 0.46 & 0.44 & 0.39 & 0.42 & 0.43 & 0.43 & 0.78 \\
5 & 0.58 & 0.63 & 0.61 & 0.58 & 0.71 & 0.72 & 0.66 & 0.65 \\
6 & 0.87 & 0.97 & 0.95 & 0.91 & 0.93 & 1.02 & 1.03 & 1.07 \\
7 & 1.10 & 1.10 & 1.07 & 1.07 & 1.13 & 1.13 & 1.11 & 1.02 \\
8 & 0.70 & 0.70 & 0.70 & 0.69 & 0.76 & 0.73 & 0.71 & 0.77 \\
9 & 1.41 & 1.44 & 1.42 & 1.36 & 1.49 & 1.53 & 1.48 & 1.47 \\
10 & 0.81 & 0.85 & 0.85 & 0.81 & 0.82 & 0.79 & 0.79 & 0.90 \\
11 & 1.03 & 1.03 & 1.06 & 1.09 & 1.13 & 1.11 & 1.07 & 0.97 \\
12 & 1.59 & 1.68 & 1.67 & 1.65 & 1.74 & 1.67 & 1.62 & 1.61 \\
13 & 1.02 & 1.02 & 1.02 & 1.00 & 1.07 & 1.09 & 1.08 & 1.26 \\
14 & 1.67 & 1.60 & 1.56 & 1.60 & 1.70 & 1.73 & 1.76 & 1.81 \\
15 & 1.68 & 1.68 & 1.69 & 1.79 & 1.91 & 1.99 & 1.98 & 1.99 \\
16 & 1.23 & 1.19 & 1.19 & 1.21 & 1.33 & 1.39 & 1.36 & 1.39 \\
17 & 0.62 & 0.58 & 0.58 & 0.58 & 0.59 & 0.60 & 0.58 & 0.60 \\
\hline
\end{tabular}

Regional economy can be expanded by improving collaboration between Mamuju Regency and its hinterland.Those collaborations can be made on sectors such agriculture, mining, manufactured industries, power and electricity, water and sewages, construction, trade and retails, transportation and warehousing, hotel and restaurants, information and communication, finance and insurance, real estate, business services, government, defense and social security, education, health and social activities and ungrouped services.

Mamuju Regecy can support economy ofMajene Regency by supplying products of water and sewage, construction, business services and health and social activities. On the other hand, businessmen in Majene Regency can expand their activities on real estates in Mamuju Regency.

Mamuju Regecy can support economy of Polewali Mandar Regency by supplying products 
of construction, transportation and warehousing, government, defense and social activities and education. On the other hand, businessmen in Polewali Mandar Regency can expand their activities on real estates in Mamuju Regency.

Mamuju Regecy can support economy of PasangkayuRegency by supplying products of mining, power and electricity, water and sewages, trade and retails, transportation and warehousing, hotel and restaurants, information and communication, finance and insurance, business services, government, defense and social security, education and ungrouped services. On the other hand, businessmen in Pasangkayu Regency can expand their activities on agricultureand manufactured industries in Mamuju Regency.

Mamuju Regecy can support economy of Central Mamuju Regency by supplying products of mining, power and electricity, water and sewages, construction, trade and retails, transportation and warehousing, hotel and restaurants, information and communication, finance and insurance, business services, government, defense and social security, education, health and social activities and ungrouped services. On the other hand, businessmen in Central Mamuju Regency can expand their activities on agriculture and real estates in Mamuju Regency.

Mamuju Regecy can support economy of Mamasa Regency by supplying products of mining, power and electricity, water and sewage, construction, transportation and warehousing, information and communication and ungrouped services. On the other hand, businessmen in Mamasa Regency can expand their activities on real estates in Mamuju Regency.

\section{Conclusion}

Mamuju Regency has many opportunities to expand its growth by establishing a mutual relationship with its hinterlands. Businessmen in Mamuju Regency can increase its production to supply other regencies on water and sewagessector along with other sectors such as construction, business services, health and social activities, transportation and warehousing, government, defense and social security, education, mining, power and electricity, trade and retails, hotel and restaurants, information and communication, finance and insurance and ungrouped services. Businessmen in other regencies can expand their production to supply Mamuju Regency with products from real estate, agriculture and manufactured industries.

\section{References}

[1] Ascani, A., Crescenzi, R., Iammarino, S. (2012) Regional Economic Development: A Review. WP1/03 Search Working Study. Retrieved from http://www.ub.edu/searchproject/wpcontent/uploads/2012/02/WP-1.3.pdf

[2] Berliant, M. (2005) Central Place Theory. Research Gate June 2005. Retrieved from:

https://www.researchgate.net/publication/ 23749688

[3] BPS Majene (2019) Tabel 1. PDRB Kabupaten Majene Atas Dasar Harga Berlaku Menurut Lapangan Usaha Tahun 2010-2017 (Juta Rupiah). Retrieved from https://majenekab.bps.go.id/dynamictable /2017/07/05/5/tabel-1-pdrb-kabupatenmajene-atas-dasar-harga-berlakumenurut-lapangan-usaha-tahun-20102016-juta-rupiah-.html

[4] BPS Mamasa (2019) PDRB Kabupaten Mamasa Atas Dasar Harga Berlaku Menurut Lapangan Usaha Tahun 20102018. Retrieved from https://mamasakab.bps.go.id/dynamictabl e/2019/10/17/20/pdrb-kabupatenmamasa-atas-dasar-harga-berlakumenurut-lapangan-usaha-tahun-20102018.html

[5] BPS Mamuju (2019) [Seri 2010] PDRB Kabupaten Mamuju Atas Dasar Harga Berlaku Menurut Lapangan Usaha (Juta Rupiah), 2010-2018. Retrieved from https://mamujukab.bps.go.id/dynamictabl e/2017/07/05/111/-seri-2010-pdrb- 
kabupaten-mamuju-atas-dasar-hargaberlaku-menurut-lapangan-usaha-jutarupiah-2010-2018.html

[6] BPS Mamuju Tengah (2019) [Seri 2010] PDRB Kabupaten Mamuju Tengah Atas Dasar Harga Berlaku Menurut Lapangan Usaha (Juta Rupiah), 2013-2018. Retrieved from https://mamujutengahkab.bps.go.id/dyna mictable/2017/12/22/11/-seri-2010-pdrbkabupaten-mamuju-tengah-atas-dasarharga-berlaku-menurut-lapangan-usahajuta-rupiah-2013-2018.html

[7] BPS Pasangkayu (2019) PDRB Menurut Lapangan Usaha Atas Dasar Harga Berlaku di Kabupaten Pasangkayu 20102018 (Juta Rupiah). Retrieved fromhttps://mamujuutarakab.bps.go.id/dy namictable/2015/10/16/2/pdrb-menurutlapangan-usaha-atas-dasar-harga-berlakudi-kabupaten-pasangkayu-2010-2018juta-rupiah-.html

[8] BPS Polewali Mandar (2019) [Seri 2010] PDRB Kabupaten Polewali Mandar Atas Dasar Harga Berlaku Menurut Lapangan Usaha Tahun 2010-2018 (Juta Rupiah). Retrieved from https://polewalimandarkab.bps.go.id/dyn amictable/2017/07/05/97/-seri-2010pdrb-kabupaten-polewali-mandar-atasdasar-harga-berlaku-menurut-lapanganusaha-tahun-2010-2018-juta-rupiah-.html

[9] Hanif, Md. A., Tabassum, A., Hauque, A. M., Hossain, Md. R., Jahan, S., Debnath, A. K. (2015) Determination of Location Quotient (LQ) of Districts of Bangladesh based on Level of Urbanization and their Regionalization to Study the Regional Disparities based on Indicators of Urban Area of Bangladesh. European Academic Research Vol.III, Perspective 2/May 2015.

https://www.researchgate.net/publication/ 281462793

[10] OECD (2008) Port Competition and Hinterland Connections: Summary and
Conclusion. Discussion Study No. 200819 October 2008. Joint Transport Research Centre Round Table Paris 1011 April 2008. Retrieved from: https://www.oecdilibrary.org/docserver/235100656678.pdf ?expires $=1541142618 \&$ id $=$ id\&accname $=$ guest\&checksum=DC5BAD91E670A52 58AC5E67D22C5DEEA

[11] Srotebeck, F. (2010) The Location Quotient-Assembly and Application of Methodological Enhancements. MPRA Study No. 47988. Retrieved from: http://mpra.ub.uni-muenchen.de/47988/

[12] Visser, J., Konings, R., Pielage, B. J., Wiegmans, B. (2007) A New Hinterland Transport Concept for The Port of Rotterdam: Organisational and/or Technological Challenges? Retrieved from:

https://ageconsearch.umn.edu/bitstream/2 07936/2/2007_9B_Hinterland_study.pdf

[13] Welman L., Ferreira S. L. A. (2016) The Co-evolution of Saldanha Bay (Town and Hinterland) and its Port. Local Economy: The Journal of the Local Economy Policy Unit Vol.31. Sage Journals. Retrieved from:

https://doi.org/10.1177/02690942156238 49 